Grand Valley State University

ScholarWorks@GVSU

$12-23-2014$

\title{
How Increasing Personal Care Service Might Delay or Prevent Nursing Home Placement
}

\author{
Sandra L. Spoelstra \\ Grand Valley State University, spoelsts@gvsu.edu \\ Charles W. Given \\ Michigan State University \\ Tracy DeKoekkoek \\ Michigan State University \\ Monica Schueller \\ Michigan State University
}

Follow this and additional works at: https://scholarworks.gvsu.edu/kcon_articles

Part of the Nursing Commons

\section{ScholarWorks Citation}

Spoelstra, Sandra L.; Given, Charles W.; DeKoekkoek, Tracy; and Schueller, Monica, "How Increasing Personal Care Service Might Delay or Prevent Nursing Home Placement" (2014). Peer Reviewed Articles. 20.

https://scholarworks.gvsu.edu/kcon_articles/20

This Article is brought to you for free and open access by the Kirkhof College of Nursing at ScholarWorks@GVSU. It has been accepted for inclusion in Peer Reviewed Articles by an authorized administrator of ScholarWorks@GVSU.

For more information, please contact scholarworks@gvsu.edu. 


\title{
How increasing personal care service might delay or prevent nursing home placement
}

\author{
Sandra L. Spoelstra, Charles W. Given, Tracy DeKoekkoek, \\ Monica Schueller
}

\begin{abstract}
Aims: There is a pressing need to retain dually eligible elderly Medicare and Medicaid beneficiaries in the community. The objective of this study was to examine median personal care services (PCS) hours, and how increasing PCS to the median (for those below), might delay nursing home placement (NHP) and save cost. Methods: Retrospective study of PCS hours, costs, and NHP in a statewide home and community based waiver program in the Midwest serving 6525 dually eligible Medicare-Medicaid beneficiaries aged 65 and older. Two Minimum Data Set-Home Care assessments and Medicaid claim files were examined to identify PCS hours and cost. A model was developed to estimate costs of increasing PCS to the median to compare retaining at home compared to NHP. Results: Participants with PCS greater than the median hours had a NHP rate of $25 \%$, compared to $36 \%$ for those with less than median PCS hours. To
\end{abstract}

Sandra L. Spoelstra1, Charles W. Given², Tracy DeKoekkoek $^{3}$, Monica Schueller ${ }^{4}$

Affiliations: ${ }^{1} \mathrm{PhD}, \mathrm{RN}$ Michigan State University College of Nursing 1355 Bogue Street, Room C342, East Lansing, MI, USA; ${ }^{2} \mathrm{PhD}$, Michigan State University Institute for Health Policy instead of Department of Family Medicine, B106 Clinical Center, East Lansing, MI, USA; ${ }^{3} \mathrm{RN}$, Michigan State University College of Nursing 1355 Bogue Street, Room C340L, East Lansing, MI, USA; 'BA, Michigan State University College of Nursing 1355 Bogue Street, Room C340N, East Lansing, MI, USA.

Corresponding Author: Sandra Lee Spoelstra, Michigan State University College of Nursing instead of College of Human Medicine, 1355 Bogue Street, Room C342, East Lansing, MI 48824, USA; Ph: (517) 353-8681; E-mail: spoelst5@msu.edu

Received: 14 October 2014

Accepted: 10 November 2014

Published: 13 December 2014 attain a 25\% NHP rate of participants below the median, we estimated savings by subtracting the usual monthly cost of the waiver (\$960) from the monthly NHP cost and adding the cost of the additional PCS (\$15.67/hour). For this sample, a total of $\$ 155,088$ per month could be saved by adding PCS hours to the median. Conclusion: The NHP rate could be reduced from $25-36 \%$, and savings of nearly $\$ 2$ million a year could be realized by increasing PCS hours to the median and retaining participants in the waiver program. Evaluating waiver participants who are below the median number and increasing those who need it could help retain participants in the home setting, where they most want to be, and allow for tremendous cost savings.

Keywords: Dually eligible, Home and CommunityBased Waiver Program, Medicare and Medicaid, Nursing home placement, Personal care services

\section{How to cite this article}

Spoelstra SL, Given CW, DeKoekkoek T, Schueller M. How increasing personal care service might delay or prevent nursing home placement. Edorium J Public Health 2014;1:7-15.

Article ID: 100001P16SS2014

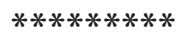

doi:10.5348/p16-2014-2-OA-2

\section{INTRODUCTION}

With adults aged 65 and older currently comprising $15 \%$ of the population and growing exponentially [1], concern is mounting regarding how to care for 


\section{EDORiUM Journals}

this increasing demographic group. Particularly, it is important to find ways to deliver high-quality care tailored to the needs of participants in order to allow these individuals to remain living in their communities. Such concerns are particularly relevant to state Medicaid programs serving elderly participants who are medically indigent, and therefore dually eligible for coverage under both Medicare and Medicaid.

Nursing home placement (NHP) is costly, averaging over $\$ 70,000$ per year for one individual [2]. In the United States, the cost of NHP totaled $\$ 138.4$ billion in 2008, with Medicaid and Medicare payments totaling $\$ 56.3$ billion and $\$ 25.7$ billion, respectively [2]. By 2020, total NHP costs are projected to exceed $\$ 250$ billion annually [2]. NHP among the dually eligible may be particularly important, as these individuals tend to be in worse health, use a disproportionate amount of resources, and are substantially more likely to be institutionalized. Beyond escalating financial concerns, there are a constellation of potentially negative outcomes associated with NHP for older adults, such as infections, falls and cognitive decline [3-6]. Older adults prefer to remain in their own homes [7], but are forced into NHP because community-based supports are inadequate to meet their needs. Two studies focusing on delaying NHP among frail, low-income, dually eligible elders found that use of community-based services, which included the full range of supports for living at home, delayed NHP; and that when services were discontinued at the end of the studies, the NHP rate increased 40\% [8-9].

More research is needed to develop strategies to support and retain the elderly in their homes. However, such research must balance retention in home-based programs with the costs and capacity of these programs to meet participants' needs, and delivering high-quality care.

The goal of this research was to examine the use and cost of personal care services (PCS) and how these would predict the likelihood of NHP for dually eligible home and community-based participants covered under a 1915c Home and Community Based Waiver (HCBW) agreement of the Social Security Act. The researchers for this project chose to examine PCS, as these are the most common type of services utilized and also the highest cost of services provided in the HCBW program. For this study, personal care services are considered to be assistance with bathing, walking, ambulation and other activities of daily living. The researchers developed a model to estimate the cost of increased PCS hours compared to savings associated with remaining in the HCBW program in the community relative to NHP. Their goal was to describe how NHP might be delayed or prevented by increasing the hours of PCS in the HCBW program and to review the possible cost savings implications that could be attained by using more PCS hours and delaying NHP in a HCBW program.

The researchers used data contained in the Minimum Data Set for Home Care (MDS-HC [version 2]) linked to the Medicaid claims files. The Medicaid files contained cost and status codes from the state data warehouse signifying NHP or continued care in the HCBW program. The researchers also used vital statistics to identify subjects who were deceased. The intent of the study was to identify usage of PCS hours and how it influenced NHP rates and to explore if increased PCS hours could delay or prevent NHP.

\section{METHODS AND MATERIALS}

To be eligible for the federal 1915c HCBW waiver program in the State of Michigan, participants must meet Medicaid-defined nursing facility level-of-care criteria. This includes a need for those requiring assistance with instrumental activities of daily living, to have earnings at or below 300\% of federal poverty level, and to have a caregiver who agrees to provide assistance to the participant at home. In this study, the researchers identified a cohort of persons 65 years of age and older who entered this waiver program between January 2002 and the end of December 2007. This interval was selected because it represented a period when the Michigan waiver program experienced a number of changes in financing and policy [10]; and for which there was complete information.

Following completion of data use agreement and Institutional Review Board approvals, data from MDSHC, Medicaid claims files, and vital statistics from 2002 to 2007 were linked and a dataset was created. The MDS-HC assessments and Medicaid claim files were obtained from the State Medicaid data warehouse and Michigan death certificate information was obtained from Michigan Department of Community Health Vital Statistics. The MDS-HC, a modification of the Minimum Data Set nursing home version, is a person-centered assessment with uniform standards for the collection of essential nursing data assessing multiple domains [11]. The MDS-HC has been widely tested, much of this work done in the State of Michigan waiver program [12-13]. The claims files consisted of bills submitted, and thus represent charges for services. These files also identified enrollment in the HCBW program and NHP.

To define the analysis sample, all eligible cases were compared against death certificate information from the Vital Records. 3983 participants died while in the HCBW program and were subsequently removed from the study. The researchers included at least two MDS-HC assessments of each participant; the second-to-last and last assessments available during the analysis period. This was done to identify a median number of PCS hours so the researchers could examine whether PCS hours increased, decreased, or did not change for those who stayed in the waiver program which was compared to those who had NHP. This was important, as the researchers' goal 


\section{EDORiUM Journals}

was to identify if increasing PCS hours would delay or prevent NHP. Thus, 1729 participants with only a single assessment were removed.

The researchers then removed 1567 participants who enrolled in the program later than December 31, 2005 as they were not in the program over 24 months. There were also 764 participants removed as they were lost to followup (i.e., no information was found regarding whether they stayed in the waiver program or had NHP, nor was there a death certificate prior to December, 31 2007). The remaining analysis sample for this study was 6525 (Figure 1).

The researchers then used variables from the literature (Table 1) that influence NHP, applied them to the MDSHC data and developed a PCS model using participants who had moderate likelihood of transfer to a nursing home. The researchers examined age, gender, race, cognition, activities of daily living (ADLs), prior NHP, hospitalizations, falls, and how the change between the next to last assessment and the last assessment increased the patients' risk of NHP.

The NHP risk index, specificity of 0.4 and sensitivity of 0.9, predicted NHP in this population. Hospitalization and prior NHP were from the Medicaid claim files and all other information was from the MDS-HC. Age was a continuous variable and gender was male or female, while race was categorized as Caucasian, African-American or other. ADLs (dressing, eating, toileting, personal hygiene and bathing) were scored zero to six, with a score of two or greater constituting as dependency. These variables have reliability and scalar properties [11].

Cognition was based on an instrument developed by Morris et al. [14], with scores ranging from zero to six, with a score of two or greater qualifying patients as cognitively impaired. Falls were based on a question which asked participants to recall the number of falls that occurred

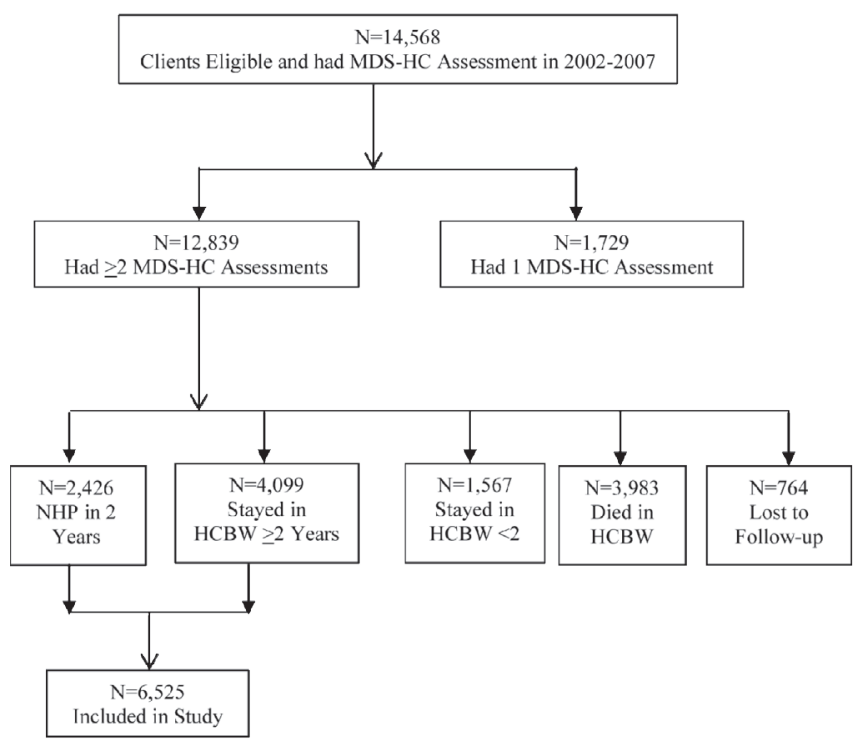

Figure 1: CONSORT Chart of Analysis Sample. in the last 180 days. A three-level approach to assessing change was used in all cases with no deterioration further divided into whether participants had ADL dependencies, more than two cognitive deficits, or falls reported at last MDS assessment. Those cases that remained were either independent at both assessments or improved at the final assessment when compared with their second-to-last assessment. Very few cases reported improvement in any of these three dimensions.

Using the variables of age, PCS hours and cost for the second-to-last and last assessment, as well as whether the participant had NHP or remained in the HCBW program, researchers then identified the median PCS hours and costs for such services. Once complete, NHP rates were identified for subjects with less than the median hours of PCS versus patients with equal to or greater than the median hours of PCS. Researchers developed models based on the assumption that increasing PCS hours to the median level for those participants who were below the median and had a higher rate of NHP could reduce the rate of NHP to the same level as participants who had the median hours of PCS. Four categories of participants in the 30 days prior to the last assessment were identified. This included:

(1) those above the median but decreased PCS hours

(2) below the median decreased PCS hours

(3) had no change in PCS hours and were below the median

(4) increased PCS hours and were below median. Researchers then utilized the State of Michigan average HCBW and NHP cost per month to calculate the amount saved by retaining those participants who had increased PCS hours up to the median and delaying or preventing NHP. This allowed researchers to determine the potential for cost savings due to delaying or preventing NHP after increasing PCS hours to the median

\section{RESULTS}

Analysis were performed using SASß 9.2 software with logistic procedures. Table 1 reports the factors in the risk index by NHP or remaining in the HCBW. The majority were females $(70 \%)$. Those aged 75 or older had NHP rates of $74.6 \%(\mathrm{n}=1809)$ compared to $25.4 \%$ $(\mathrm{n}=617)$ in those aged 65 to 74 . Caucasians had higher NHP $(79.2 \%, n=1922)$ than those remaining in the HCBW (73.2\%, N=3002); while African-Americans had higher rates of remaining in the HCBW 23.6\% ( $n=969)$ than NHP $(17.0 \%, \mathrm{~N}=412)$.

Those with prior NHP had higher rates of NHP (35.6\%, $\mathrm{n}=864)$ than those remaining in HCBW $(18.7 \%, \mathrm{n}=768)$. More who had NHP $(13.8 \%, n=334)$ wanted another living environment, than those remaining in HCBW $(3.1 \%, n=127)$. Prior hospitalization in the last 90 days occurred at a higher rate for those who had NHP (13.2\%, 


\section{EDORiUM Journals}

Table 1: Descriptive statistics of socio-demographic and factors in the risk index by participants who stayed in the home and community based waiver program (HCBW) or had nursing home placement (NHP)

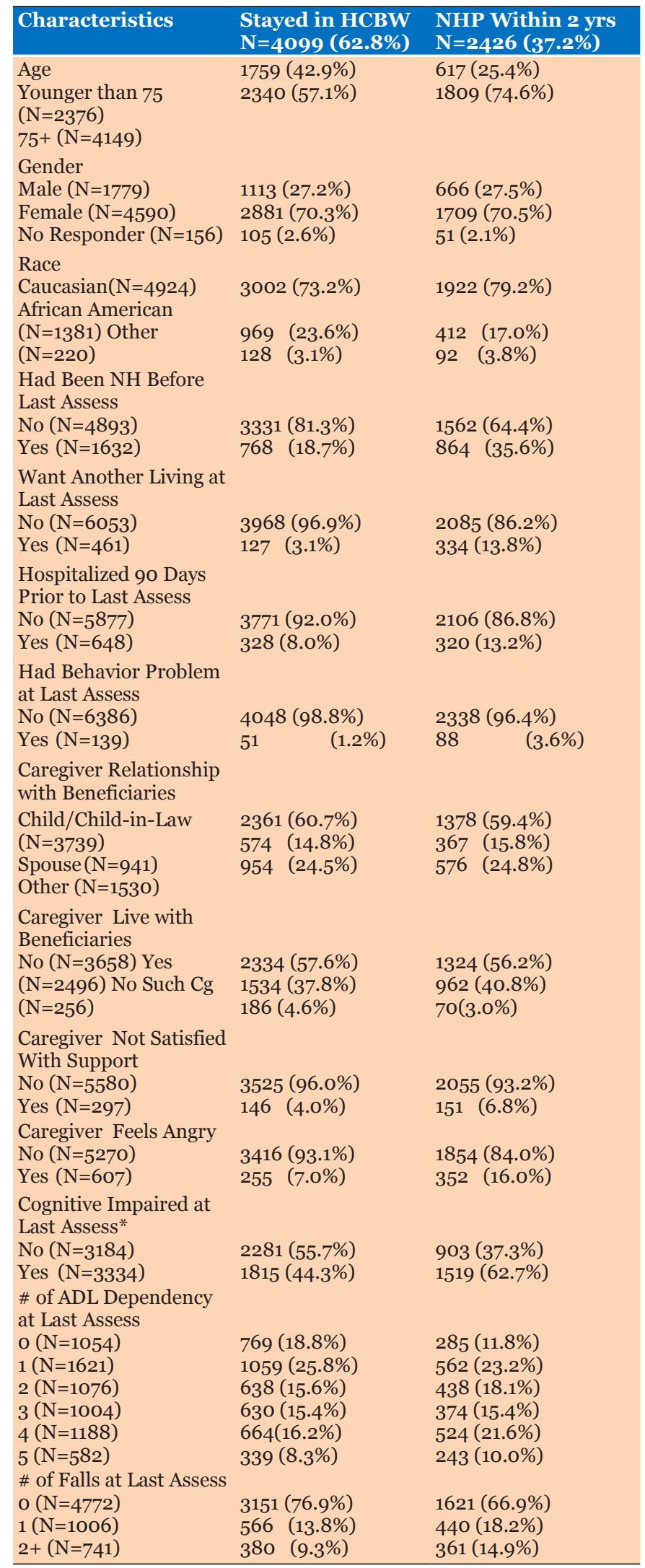

*Based on John N. Morris's definition, cognitive performance score as $2+$ is impaired. $\mathrm{n}=320)$ than for those remaining in $\mathrm{HCBW}(8.0 \%$, $\mathrm{n}=127)$. Minimal differences were found in behavior problems, caregiver relationship type, caregiver living with participant or not satisfied with support as given in Table 1.

Participants with caregivers who felt angry had higher NHP $(16.0 \%, n=352)$ than those who had angry caregivers and remained in the HCBW $(7.0 \%, \mathrm{n}=255)$. Cognitive impairment, ADL dependency and the number of falls were all increased for the NHP group.

Table 2 tells whether the seven risk groups segmented by PCS hours were greater than, equal to, or less than the median. These results were each categorized as to whether participants had an increase, no change or a decrease in PCS hours between the second-to-last and last MDS-HC assessment sorted by NHP or stayed in the HCBW.

Table 3 reports on the rate of NHP (range of 25 to 45\%) and median PCS hours (range of 33 to 45) for risk groups three through seven. Risk groups one and two were not examined as they were at lower risk of NHP.

Participants at the median or without a decrease in PCS had a 25\% NHP rate and 34 hours of PCS on average. To attain this 25\% NHP rate for those who were below the median and had decreased PCS hours, a total of 3212 hours of PCS need to be added, making the mean (Standard Deviation [SD]) and median PCS hours 44.5 (23.2) and 34, respectively. This would reduce the number of participants with NHP to 68, saving 32 participants in the HCBW.

To determine the total cost savings to retain those 32 participants at home, researchers took the NHP rate $\$ 112,000\left(32^{*} \$ 3,500\right)$ and subtracted the HCBW rate $\$ 29,888$ (32* $\$ 960$ [average cost for risk index group $4])$ and cost of adding PCS hours $\$ 50,332\left(3212^{*} \$ 15.67\right.$ [average cost per hour of PCS]) for a total savings of $\$ 31,780$ to retain 32 participants in the $\operatorname{HCBW}(\$ 112,000-$ $\$ 29,888-\$ 50,332)$.

To attain this 25\% NHP rate for those who were below the median and had decreased PCS hours, a total of 3,777 hours of PCS should be added, making the mean (SD) and median PCS hours 38.5 (21.0) and 34, respectively. This would reduce the number of participants with NHP to 53, saving 33 participants in the HCBW.

To calculate the total cost savings to retain those 33 participants at home, researchers took the NHP rate of $\$ 115,500$ ( $\left.33^{*} \$ 3500\right)$ subtracted the HCBW rate of $\$ 30,822\left(33^{*} \$ 960\right)$ and the cost of adding PCS hours at $\$ 59,186\left(3777^{*} \$ 15.67\right)$ for a total savings of $\$ 25,492$ $(\$ 115,500-\$ 30,822-\$ 59,186)$ to retain 33 participants in the HCBW.

To attain the 25\% NHP rate for those who had no change in PCS hours and were below the median, a total of 14,864 hours of PCS should be added, adjusting the mean (SD) and median PCS hours 34 (0.0) and 34, respectively. This would reduce the number of participants with NHP to 113 and save 50 participants in the HCBW. 


\section{EDORiUM Journals}

Edorium J Public Health 2014;1:7-15.

Table 2: Risk groups increased, no change, or decreased in personal care service (PCS) hours between the second to last and last MDS-HC assessment and atayed in home and community based waiver (HCBW) or had nursing home placement (NHP)

\begin{tabular}{|c|c|c|c|c|}
\hline $\begin{array}{l}\text { Risk } \\
\text { Groups } \\
\text { Total } \\
\mathbf{N = 6 5 2 5}\end{array}$ & $\begin{array}{l}\text { PCS hours > } \\
\text { median or } \\
\leq \text { median }\end{array}$ & $\begin{array}{l}\text { PCS Hours } \\
>\text { median or } \\
\leq \text { median, } \\
\text { increased, } \\
\text { no change or } \\
\text { decrease }\end{array}$ & $\begin{array}{l}\text { Stayed } \\
\text { in } \\
\text { HCBW } \\
N=4099 \\
(62.8 \%)\end{array}$ & $\begin{array}{l}\text { NHP }<2 \\
\text { yrs } \\
\text { N=2426 } \\
(37.2 \%)\end{array}$ \\
\hline $\begin{array}{l}\text { Risk } \\
\text { Group } 1\end{array}$ & $\begin{array}{l}\text { PCS Hours } \\
\text { >median }\end{array}$ & $\begin{array}{l}\text { Increased PCS } \\
\mathrm{N}=274(30.8 \%)\end{array}$ & $\begin{array}{l}221 \\
(80.7 \%)\end{array}$ & $\begin{array}{l}53 \\
(19.3 \%)\end{array}$ \\
\hline \multirow{5}{*}{$\begin{array}{l}\mathrm{N}=1549 \\
(23.6 \%)\end{array}$} & \multirow[t]{2}{*}{$\mathrm{N}=787(50.8 \%)$} & $\begin{array}{l}\text { No Change in PCS } \\
\mathrm{N}=288(36.2 \%)\end{array}$ & $\begin{array}{l}155 \\
(87.1 \%)\end{array}$ & $\begin{array}{l}70 \\
(24 \cdot 3 \%)\end{array}$ \\
\hline & & $\begin{array}{l}\text { Decreased in PCS } \\
\mathrm{N}=288(36.6 \%)\end{array}$ & $\begin{array}{l}218 \\
(75 \cdot 7 \%)\end{array}$ & $\begin{array}{l}70 \\
(24.3 \%)\end{array}$ \\
\hline & $\begin{array}{l}\text { PCS Hours } \\
\leq \text { median }\end{array}$ & $\begin{array}{l}\text { Increased PCS } \\
\mathrm{N}=183(24.0 \%)\end{array}$ & $\begin{array}{l}135 \\
(73.8 \%)\end{array}$ & $\begin{array}{l}48 \\
(26.2 \%)\end{array}$ \\
\hline & \multirow[t]{2}{*}{$\mathrm{N}=762(49.2 \%)$} & $\begin{array}{l}\text { No Change in PCS } \\
\mathrm{N}=550(72.2 \%)\end{array}$ & $\begin{array}{l}449 \\
(81.6 \%)\end{array}$ & $\begin{array}{l}101 \\
(18.4 \%)\end{array}$ \\
\hline & & $\begin{array}{l}\text { Decreased in PCS } \\
\mathrm{N}=76(3.8 \%)\end{array}$ & $\begin{array}{l}46 \\
(60.5 \%)\end{array}$ & $\begin{array}{l}30 \\
(39.8 \%)\end{array}$ \\
\hline $\begin{array}{l}\text { Risk } \\
\text { Group } 2\end{array}$ & $\begin{array}{l}\text { PCS Hours } \\
>\text { median }\end{array}$ & $\begin{array}{l}\text { Increased PCS } \\
\mathrm{N}=230(40.0 \%)\end{array}$ & $\begin{array}{l}183 \\
(79.8 \%)\end{array}$ & $\begin{array}{l}47 \\
(20.4 \%)\end{array}$ \\
\hline \multirow{5}{*}{$\begin{array}{l}\mathrm{N}=1213 \\
(18.5 \%)\end{array}$} & \multirow[t]{2}{*}{$\mathrm{N}=580(47.8 \%)$} & $\begin{array}{l}\text { No Change in PCS } \\
\mathrm{N}=142(24.5 \%)\end{array}$ & $\begin{array}{l}118 \\
(83.7 \%)\end{array}$ & $\begin{array}{l}23 \\
(16.3 \%)\end{array}$ \\
\hline & & $\begin{array}{l}\text { Decreased in PCS } \\
\mathrm{N}=208(35.5 \%)\end{array}$ & $\begin{array}{l}136 \\
(65.4 \%)\end{array}$ & $\begin{array}{l}72 \\
(34.6 \%)\end{array}$ \\
\hline & $\begin{array}{l}\text { PCS Hours } \\
\leq \text { median }\end{array}$ & $\begin{array}{l}\text { Increased PCS } \\
\mathrm{N}=151(23.9 \%)\end{array}$ & $\begin{array}{l}108 \\
(71.5 \%)\end{array}$ & $\begin{array}{l}43 \\
(28.5 \%)\end{array}$ \\
\hline & \multirow[t]{2}{*}{$\mathrm{N}=633(52.2 \%)$} & $\begin{array}{l}\text { No Change in PCS } \\
\mathrm{N}=433(68.4 \%)\end{array}$ & $\begin{array}{l}343 \\
(79.2 \%)\end{array}$ & $\begin{array}{l}90 \\
(20.8 \%)\end{array}$ \\
\hline & & $\begin{array}{l}\text { Decreased in PCS } \\
\mathrm{N}=50(7.7 \%)\end{array}$ & $\begin{array}{l}42 \\
(84.0 \%)\end{array}$ & $8(16.0 \%)$ \\
\hline $\begin{array}{l}\text { Risk } \\
\text { Group } 3\end{array}$ & $\begin{array}{l}\text { PCS Hours } \\
\text { >median }\end{array}$ & $\begin{array}{l}\text { Increased PCS N= } \\
267(40.0 \%)\end{array}$ & $\begin{array}{l}193 \\
(72.3 \%)\end{array}$ & $\begin{array}{l}74 \\
(27.8 \%)\end{array}$ \\
\hline \multirow[t]{5}{*}{$\begin{array}{l}\mathrm{N}=1402 \\
(22.0 \%)\end{array}$} & \multirow[t]{2}{*}{$\mathrm{N}=677(48.3 \%)$} & $\begin{array}{l}\text { No Change in PCS } \\
\mathrm{N}=138(20.4 \%)\end{array}$ & $\begin{array}{l}112 \\
(81.2 \%)\end{array}$ & $\begin{array}{l}26 \\
(18.9 \%)\end{array}$ \\
\hline & & $\begin{array}{l}\text { Decreased in PCS } \\
\mathrm{N}=272(39.9 \%)\end{array}$ & $\begin{array}{l}172 \\
(63.2 \%)\end{array}$ & $\begin{array}{l}100 \\
(36.8 \%)\end{array}$ \\
\hline & $\begin{array}{l}\text { PCS Hours } \\
\leq \text { median }\end{array}$ & $\begin{array}{l}\text { Increased PCS N= } \\
210(30.0 \%)\end{array}$ & $\begin{array}{l}124 \\
(59.9 \%)\end{array}$ & $\begin{array}{l}86 \\
(40.1 \%)\end{array}$ \\
\hline & $\mathrm{N}=725(51.7)$ & $\begin{array}{l}\text { No Change in PCS } \\
\mathrm{N}=453(62.5 \%)\end{array}$ & $\begin{array}{l}290 \\
(64.0 \%)\end{array}$ & $\begin{array}{l}163 \\
(36.0 \%)\end{array}$ \\
\hline & & $\begin{array}{l}\text { Decreased in PCS } \\
\mathrm{N}=62(7.5 \%)\end{array}$ & $\begin{array}{l}33 \\
(53.2 \%)\end{array}$ & $\begin{array}{l}29 \\
(46.8 \%)\end{array}$ \\
\hline $\begin{array}{l}\text { Risk } \\
\text { Group } 4\end{array}$ & $\begin{array}{l}\text { PCS Hours } \\
\text { > median }\end{array}$ & $\begin{array}{l}\text { Increased PCS } \\
\mathrm{N}=184(40.3 \%)\end{array}$ & $\begin{array}{l}121 \\
(65.8 \%)\end{array}$ & $\begin{array}{l}64 \\
(34.2 \%)\end{array}$ \\
\hline \multirow[t]{3}{*}{$\begin{array}{l}N=967 \\
(14.8 \%)\end{array}$} & \multirow[t]{3}{*}{$\mathrm{N}=457(47 \cdot 3 \%)$} & & & \\
\hline & & $\begin{array}{l}\text { No Change in PCS } \\
\mathrm{N}=81(17.8 \%)\end{array}$ & $\begin{array}{l}58 \\
(71.6 \%)\end{array}$ & $23(28.4)$ \\
\hline & & $\begin{array}{l}\text { Decreased in PCS } \\
\mathrm{N}=192(41.9 \%)\end{array}$ & $\begin{array}{l}90 \\
(46.9 \%) \\
\end{array}$ & $\begin{array}{l}102 \\
(53.1 \%)\end{array}$ \\
\hline
\end{tabular}

Table 2: (Continued)

\begin{tabular}{|c|c|c|c|c|}
\hline $\begin{array}{l}\text { Risk } \\
\text { Groups } \\
\text { Total } \\
\text { N=6525 }\end{array}$ & $\begin{array}{l}\text { PCS hours > } \\
\text { median or } \\
\leq \text { median }\end{array}$ & $\begin{array}{l}\text { PCS Hours } \\
>\text { median or } \\
\leq \text { median, } \\
\text { increased, } \\
\text { no change or } \\
\text { decrease }\end{array}$ & $\begin{array}{l}\text { Stayed } \\
\text { in } \\
\text { HCBW } \\
\mathrm{N}=4099 \\
(62.8 \%)\end{array}$ & $\begin{array}{l}\text { NHP } \leq 2 \\
\text { yrs } \\
\text { N=2426 } \\
(37.2 \%)\end{array}$ \\
\hline & $\begin{array}{l}\text { PCS Hours } \\
\leq \text { median }\end{array}$ & $\begin{array}{l}\text { Increased PCS N= } \\
192(36.4 \%)\end{array}$ & $\begin{array}{l}83 \\
(47.7 \%)\end{array}$ & $\begin{array}{l}102 \\
(53.1 \%)\end{array}$ \\
\hline & $\mathrm{N}=528(52.7 \%)$ & $\begin{array}{l}\text { No Change in PCS } \\
\mathrm{N}=271(51.3 \%)\end{array}$ & $\begin{array}{l}154 \\
(56.8 \%)\end{array}$ & $\begin{array}{l}117 \\
(43.2 \%)\end{array}$ \\
\hline & & $\begin{array}{l}\text { Decreased in PCS } \\
\mathrm{N}=65(12.3 \%)\end{array}$ & $\begin{array}{l}32 \\
(49.2 \%)\end{array}$ & $\begin{array}{l}33 \\
(50.8 \%)\end{array}$ \\
\hline $\begin{array}{l}\text { Risk } \\
\text { Group } 5\end{array}$ & $\begin{array}{l}\text { PCS Hours } \\
>\text { median }\end{array}$ & $\begin{array}{l}\text { Increased PCS N= } \\
119(36.3 \%)\end{array}$ & $\begin{array}{l}61 \\
(51.3 \%)\end{array}$ & $\begin{array}{l}58 \\
(48.7 \%)\end{array}$ \\
\hline \multirow[t]{5}{*}{$\begin{array}{l}\mathrm{N}=663 \\
(10.1 \%)\end{array}$} & \multirow[t]{2}{*}{$\mathrm{N}=328(49.5 \%)$} & $\begin{array}{l}\text { No Change in PCS } \\
\mathrm{N}=45(13.7 \%)\end{array}$ & $\begin{array}{l}26 \\
(57.8 \%)\end{array}$ & $\begin{array}{l}19 \\
(42.2 \%)\end{array}$ \\
\hline & & $\begin{array}{l}\text { Decreased in PCS } \\
\mathrm{N}=164(50.0 \%)\end{array}$ & $\begin{array}{l}75 \\
(46.0 \%)\end{array}$ & $\begin{array}{l}88 \\
(54.0 \%)\end{array}$ \\
\hline & $\begin{array}{l}\text { PCS Hours } \\
\leq \text { median }\end{array}$ & $\begin{array}{l}\text { Increased PCS N= } \\
106(31.7 \%)\end{array}$ & $\begin{array}{l}35 \\
(33.0 \%)\end{array}$ & $\begin{array}{l}71 \\
(67.0 \%)\end{array}$ \\
\hline & \multirow[t]{2}{*}{$\mathrm{N}=334(50.5 \%)$} & $\begin{array}{l}\text { No Change in PCS } \\
\mathrm{N}=185(55.4 \%)\end{array}$ & $\begin{array}{l}82 \\
(43.9 \%)\end{array}$ & $\begin{array}{l}105 \\
(56.2 \%)\end{array}$ \\
\hline & & $\begin{array}{l}\text { Decreased in PCS } \\
\mathrm{N}=43(12.9 \%)\end{array}$ & $\begin{array}{l}12 \\
(27 \cdot 9 \%)\end{array}$ & $\begin{array}{l}31 \\
(72.1 \%)\end{array}$ \\
\hline $\begin{array}{l}\text { Risk } \\
\text { Group } 6\end{array}$ & $\begin{array}{l}\text { PCS Hours } \\
>\text { median }\end{array}$ & $\begin{array}{l}\text { Increased PCS N= } \\
58(36.3 \%)\end{array}$ & $\begin{array}{l}26 \\
(44.8 \%)\end{array}$ & $\begin{array}{l}32 \\
(55.2 \%)\end{array}$ \\
\hline \multirow[t]{5}{*}{$\begin{array}{l}\mathrm{N}=337 \\
(5.2 \%)\end{array}$} & \multirow[t]{2}{*}{$\mathrm{N}=167(49.6 \%)$} & $\begin{array}{l}\text { No Change in PCS } \\
\mathrm{N}=20(13.7 \%)\end{array}$ & $\begin{array}{l}10 \\
(50.0 \%)\end{array}$ & $\begin{array}{l}10 \\
(50.0 \%)\end{array}$ \\
\hline & & $\begin{array}{l}\text { Decreased in PCS } \\
\mathrm{N}=89(50.0 \%)\end{array}$ & $\begin{array}{l}24 \\
(27.0 \%)\end{array}$ & $\begin{array}{l}65 \\
(73.0 \%)\end{array}$ \\
\hline & $\begin{array}{l}\text { PCS Hours } \\
\leq \text { median }\end{array}$ & $\begin{array}{l}\text { Increased PCS N= } \\
44(25.9 \%)\end{array}$ & $\begin{array}{l}13 \\
(29.6 \%)\end{array}$ & $\begin{array}{l}31 \\
(70.4 \%)\end{array}$ \\
\hline & \multirow[t]{2}{*}{$\mathrm{N}=170(50.4 \%)$} & $\begin{array}{l}\text { No Change in PCS } \\
\mathrm{N}=108(63.5 \%)\end{array}$ & $\begin{array}{l}29 \\
(26.8 \%)\end{array}$ & $\begin{array}{l}79 \\
(73.2 \%)\end{array}$ \\
\hline & & $\begin{array}{l}\text { Decreased in PCS } \\
\mathrm{N}=18(10.6 \%)\end{array}$ & o & $\begin{array}{l}18 \\
(100 \%)\end{array}$ \\
\hline $\begin{array}{l}\text { Risk } \\
\text { Group } 7\end{array}$ & $\begin{array}{l}\text { PCS Hours } \\
>\text { median }\end{array}$ & $\begin{array}{l}\text { Increased PCS N= } \\
56(28.9 \%)\end{array}$ & $\begin{array}{l}21 \\
(37.5 \%)\end{array}$ & $\begin{array}{l}35 \\
(62.5 \%)\end{array}$ \\
\hline \multirow[t]{5}{*}{$\begin{array}{l}\mathrm{N}=394 \\
(11.2 \%)\end{array}$} & \multirow[t]{2}{*}{$\begin{array}{l}\mathrm{N}=1 \\
(49.2 \%)\end{array}$} & $\begin{array}{l}\text { No Change in PCS } \\
\mathrm{N}=10(5.1 \%)\end{array}$ & $7(70.0 \%)$ & $\begin{array}{l}3 \\
(30.0 \%)\end{array}$ \\
\hline & & $\begin{array}{l}\text { Decreased in PCS } \\
\mathrm{N}=128(66.0 \%)\end{array}$ & $\begin{array}{l}2 \\
(21.9 \%)^{8}\end{array}$ & $\begin{array}{l}1 \quad 0 \quad 0 \\
(78.1 \%)\end{array}$ \\
\hline & \multirow{3}{*}{$\begin{array}{l}\text { PCS Hours } \\
\leq \text { median } \\
\mathrm{N}=2 \text { o } \\
(50.8 \%)\end{array}$} & $\begin{array}{l}\text { Increased PCS N= } \\
58(29.0 \%)\end{array}$ & $\begin{array}{l}1 \\
(27.6 \%)\end{array}$ & $\begin{array}{l}4 \quad 2 \\
(72.4 \%)\end{array}$ \\
\hline & & $\begin{array}{l}\text { No Change in PCS } \\
\mathrm{N}=122(61.0 \%)\end{array}$ & ${ }_{(13.9 \%)^{7}}^{7}$ & $\begin{array}{lll}1 & 0 & 5 \\
(86.1 \%)\end{array}$ \\
\hline & & $\begin{array}{l}\text { Decreased in PCS } \\
\mathrm{N}=20(10.0 \%)\end{array}$ & $1(5.0 \%)$ & $\begin{array}{l}19 \\
(95.0 \%)\end{array}$ \\
\hline
\end{tabular}




\section{EDORiUM Journals}

Edorium J Public Health 2014;1:7-15.

Spoelstra et al. 12

www.edoriumjournalofpublichealth.com

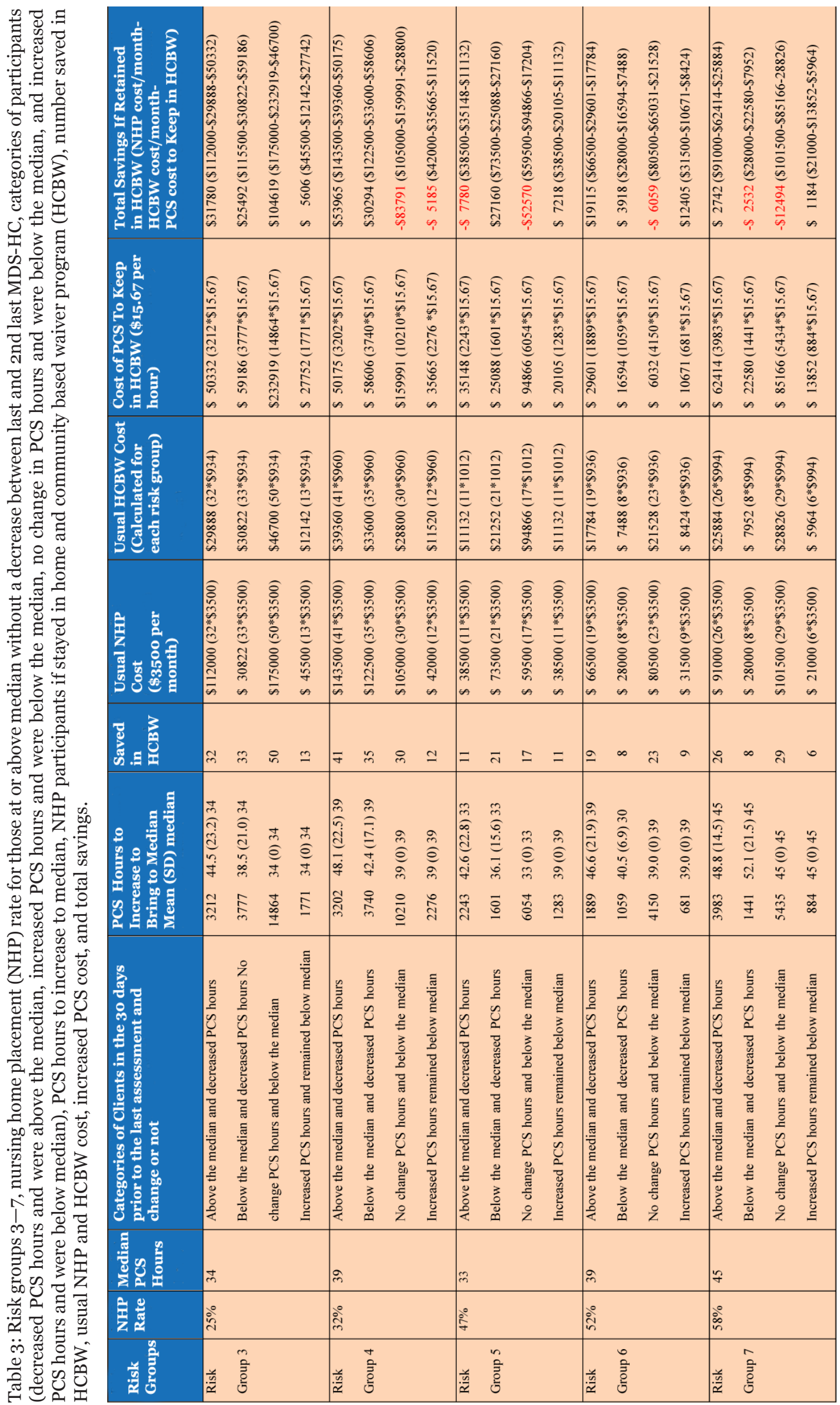




\section{EDORIUM Journals}

Edorium J Public Health 2014;1:7-15.

Spoelstra et al.

To calculate the total cost savings to retain those 50 participants at home, researchers took the NHP rate $\$ 175,000\left(50^{*} \$ 3500\right)$ and subtracted the HCBW rate $\$ 46,700\left(50^{*} \$ 960\right)$ and cost of adding PCS hours $\$ 232,919\left(14,864^{*} \$ 15.67\right)$ for a total savings of minus $\$ 104,619$ ( $\$ 175,000-\$ 232,919-\$ 46,700)$ to retain 50 participants in the HCBW.

To attain this 25\% NHP rate for those with increased PCS hours and were below median, a total of 1,771 hours of PCS should to be added, adjusting the mean (SD) and median PCS hours 34 (O) and 34, respectively. This would reduce the number of participants with NHP to 16 and save 13 participants in the HCBW.

To determine the total cost savings to retain these 13 participants at home, researchers took the NHP rate $\$ 45,500\left(13^{*} \$ 3500\right)$ and subtracted the HCBW rate $\$ 12,142\left(13^{*} \$ 960\right)$ and cost of adding PCS hours $\$ 27,752$ $\left(1771^{*} \$ 15.67\right)$ for a total savings of $\$ 5606$ ( $\$ 45,500-$ $\$ 12,142-\$ 27,742)$ to retain 13 participants in the HCBW.

In Risk group three, the total savings if 128 participants were retained in the HCBW were $\$ 167,497$ $(\$ 31,780+\$ 25,492+\$ 104,619+\$ 5,606)$ per month. Similar savings were found in Risk group six: $\$ 29,379$ (\$19115+\$3918-\$6059+\$12,405). This positive savings trend did not hold true for Risk group four, $-\$ 4,716$ $(\$ 53,965+\$ 30,294-\$ 83,791-\$ 5,185)$, Risk group five $-\$ 25,972(-\$ 7,780+\$ 27,160-\$ 52,570+\$ 7,280)$, or Risk Group seven -\$11,100 ( $\$ 2,742-\$ 2,523-\$ 12,494+\$ 1,184)$. However, overall total savings for retaining participants in Risk Group three through seven in the HCBW would be $\$ 155,088$ per month, or $\$ 1,861,056$ annually.

\section{DISCUSSION}

Adding PCS hours to waiver participants who are below the median hours of service could potentially delay or prevent NHP, and help retain participants in the home setting, allowing for significant cost savings as well as quality of life. The model developed for this analysis could be used in real time to identify participants who are below the PCS hour median. Clinicians could then conduct focused assessments of participants below the median PCS hours to determine if increasing hours of PCS could potentially delay or prevent NHP. However, it is unknown whether extenuating circumstances have occurred which required NHP, and therefore, rendering increasing PCS hours as not meaningful. Research is required to identify participants at most risk of NHP who are below the median to conduct focused, semi-structured interviews of such participants, their caregivers, care managers and supervisors to determine if modifying PCS hours to the median is desired, helpful and would potentially delay or prevent NHP. This research should conduct focused, semi-structured interviews of participants from the HCBW program whom have recently had NHP (within
30 days) to gain further insight into if modifying PCS hours would have potentially delay or prevented NHP. Future research would also focus on testing in a real world setting a small group of participants to determine if increasing PCS hours to the median, for those who are below, would delay or prevent NHP and what cost saving could be experienced.

With the increasing pressure to lower costs of health care, especially for the dually eligible, efforts such as this capitalize on existing information and allow busy care managers to focus their efforts. This, combined with clinical judgment by the waiver staff, could inform decisions about offering PCS and lead to better understanding of whether increasing PCS alters decisions to transfer patients to nursing homes, or allow them to remain at home where they most want to be.

\section{CONCLUSION}

Based on these results, increasing personal care services (PCS) may delay or prevent nursing home placement (NHP). However, what is not known is whether caregivers increase assistance following a hospitalization or when patients' condition worsens, just prior to NHP. It may also be possible that a participant move into the home of a family member or caregiver, warranting fewer PCS hours. Further study may be needed to identify what is occurring with participants just prior to NHP, and if increasing PCS hours would ultimately delay or prevent NHP in this population.

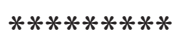

\section{Acknowledgements}

This manuscript is based on a data analysis conducted during work supported by the State of Michigan Department of Community Health Long-term Care Division. This project was funded by a State of Michigan Medicaid Match Grant "Translating Evidence into Demonstrations" (Grant number 61-9154). We would also like to acknowledge Elizabeth Gallagher, at the Michigan Department of Community Health for supporting and guiding this work. We would also like to acknowledge Mei You who conducted the majority of the data analysis for this paper.

\section{Author Contributions}

Sandra L. Spoelstra - Substantial contributions to conception and design, Acquisition of data, Analysis and interpretation of data, Drafting the article, Revising it critically for important intellectual content, Final approval of the version to be published

Charles W. Given - Analysis and interpretation of data, Revising it critically for important intellectual content, Final approval of the version to be published 


\section{EDORiUM Journals}

Tracy DeKoekkoek - Analysis and interpretation of data, Revising it critically for important intellectual content, Final approval of the version to be published

Monica Schueller - Analysis and interpretation of data, Revising it critically for important intellectual content, Final approval of the version to be published

\section{Guarantor}

The corresponding author is the guarantor of submission.

\section{Conflict of Interest}

Authors declare no conflict of interest.

\section{Copyright}

(C) 2014 Sandra L. Spoelstra et al. This article is distributed under the terms of Creative Commons Attribution License which permits unrestricted use, distribution and reproduction in any medium provided the original author(s) and original publisher are properly credited. Please see the copyright policy on the journal website for more information.

\section{REFERENCES}

1. Administration on Aging U.S. Department of Health and Human Services. A profile of older Americans: 2011. Retrieved March 1, 2013.http:// www.aoa.gov/aoaroot/aging_statistics/Profile/2011/ docs/2011profile.pdf

2. Center for Medicare and Medicaid Services. National health expenditure projections 2009-2019. Retrieved March 1, 2013 from http://www.cms.gov/ResearchStatistics-Data-and-Systems/Statistics-Trends-andReports/NationalHealthExpendData/downloads/ proj2009.pdf.

3. Smith ER, Stevens AB. Predictors of discharges to a nursing home in a hospital-based cohort. J Am Med Dir Assoc 2009 Nov;10(9):623-9.
4. Spoelstra SL, Given B, You M, Given CW. The Contribution Falls Have to Increasing Risk of Nursing Home Placement in Community-Dwelling Older Adults. Clin Nurs Res 2012 Feb;21(1):24-42.

5. Wattmo C, Wallin ÅK, Londos E, Minthon L. Risk Factors for Nursing Home Placement in Alzheimer's Disease: A Longitudinal Study of Cognition, ADL, Service Utilization, and Cholinesterase Inhibitor Treatment. Gerontologist 2011 Feb;51(1):17-27.

6. Gaugler JE, Leach CR, Clay T, Newcomer RC. Predictors of nursing home placement in African Americans with dementia. J Am Geriatr Soc 2004 Mar;52(3):445-52.

7. American Association of Retired Persons. In brief: A balancing act: State long-term care reform. In: Kassner E, Reinhard S, Fox-Grage W, Houser A, Accius J, editors 2010.

8. Fischer LR, Green CA, Goodman MJ, et al. Community-based care and risk of nursing home placement. Med Care 2003 Dec;41(12):1407-6.

9. Friedman SM, Steinwachs DM, Rathouz PJ, Burton LC, Mukamel DB. Characteristics predicting nursing home admission in the Program of All-Inclusive Care for Elderly People. Gerontologist 2005 Apr;45(2):15766.

10. D’Souza JC, James ML, Szafara KL, Fries BE. Hard times: The effects of financial strain on home care services use and participant outcomes in Michigan. Gerontologist 2009 Apr;49(2):154-65.

11. Morris JN, Fries BE, Morris SA. Scaling ADLs within the MDS. J Gerontol A Biol Sci Med Sci 1999 Nov;54(11):M546-53.

12. Fries BE, Shugarman LR, Morris JN, Simon SE, James M. A screening system for Michigan's homeand community-based long-term care programs. Gerontologist 2002 Aug;42(4):462-74.

13. Hirdes JP, Fries BE, Morris JN, et al. Home Care Quality Indicators (HCQIs) Based on the MDS-HC. Gerontologist 2004 Oct;44(5):665-79.

14. Morris JN, Fries BE, Mehr DR, et al. MDS Cognitive Performance Scale. J Gerontol 1994 Jul;49(4):M174-82.

Article citation: Spoelstra SL, Given CW, DeKoekkoek TA, Schueller M. How increasing personal care service might delay or prevent nursing home placement. Edorium J Public Health 2014;1:7-15.

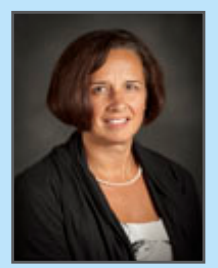

Sandra L. Spoelstra is an Assistant Professor at Michigan State University College of Nursing, E. Lansing, MI, US. She earned PhD degree in Nursing from Michigan State University. Research interests include dissemination and implementation science in vulnerable disparate populations to delay or prevent nursing home placement. E-mail: spoelst5@msu.edu 


\section{EDORiUM Journals}

Edorium J Public Health 2014;1:7-15.

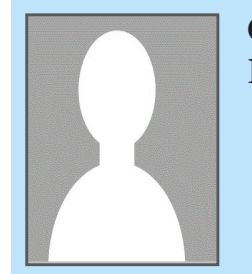

Charles W. Given is Director of the Institute of Health Care Policy at Michigan State University, E. Lansing, MI, US.

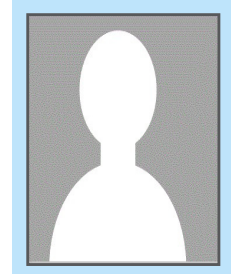

Tracy DeKoekkoek is a doctoral student at Michigan State University College of Nursing focused on aging in place.

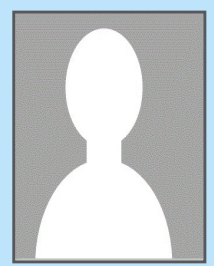

Monica Schueller is Project Manager at Michigan State University College of Nursing focused on promoting aging-in-place.

Access full text article on other devices

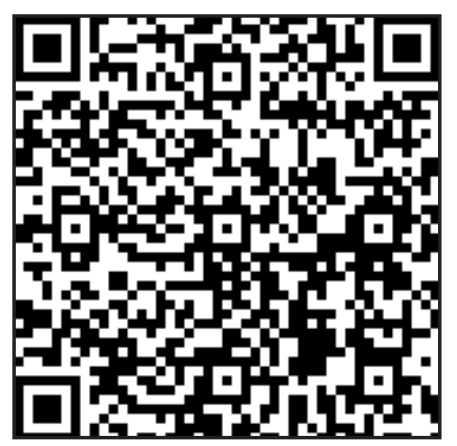

Access PDF of article on other devices

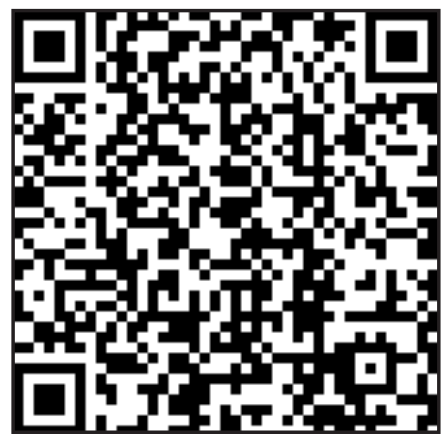

